\title{
PENGARUH SEMANGAT KERJA, HYGIENE FACTOR DAN EMPLOYEE ENGAGEMENT TERHADAP EFEKTIVITAS ORGANISASI PADA PRODI S1 AKUNTANSI UNIVERSITAS PAMULANG
}

\author{
RINI SEPTIOWATI, RAKHMAWATI OKTAVIANNA \\ Prodi Akuntansi S1, Fakultas Ekonomi, Universitas Pamulang \\ *Email : dosen01402@unpam.ac.id, dosen01146@unpam.ac.id
}

\begin{abstract}
The purpose of this study was to determine the effect of morale, hygiene factors and employee engagement on organizational effectiveness in the accounting department of Pamulang University. The research method used is quantitative research using a questionnaire, this study distributed 77 questionnaires to 77 representatives of several lecturers in the S1 Accounting University of Pamulang whose number of samples was taken by using the Slovin formula. The sample collection technique used is Purposive Sampling. Data analysis in this study was carried out using data quality tests, classic assumption tests, multiple regression analysis, coefficient of determination and hypothesis testing $(t \& F$ test). The results showed that work morale partially influences organizational effectiveness, hygiene factor partially influences organizational effectiveness and employee engagement does not affect organizational effectiveness. While simultaneous work morale, hygiene factor and employee engagement affect the effectiveness of the organization in the S1 Accounting Study Program at Pamulang University.
\end{abstract}

Keywords: morale, hygiene factor, employee engagement, organizational effectiveness.

\section{PENDAHULUAN}

\section{Latar Belakang Penelitian}

Sumber daya manusia pada perusahaan harus memiliki kontribusi untuk mencapai kesuksesan perusahaan, karena sumber daya manusia merupakan aset penting bagi perkembangan suatu perusahaan.

Sumber daya manusia merupakan aset penting bagi perkembangan perusahaan, oleh karena itu sumber daya manusia suatu perusahaan harus 
berkontribusi untuk mencapai kesuksesan (Khan et al., 2012). Baik atau buruknya sumber daya manusia yang berkontribusi dapat dinilai berdasarkan kinerjanya. Menurut Dessler (2004), kinerja karyawan merupakan prestasi aktual karyawan dibandingkan dengan prestasi yang diharapkan dari karyawan. Ketika perusahaan dapat memberi apa yang diinginkan oleh karyawan maka kinerja mereka akan mengalami peningkatan (Pratama, 2012). Terdapat beberapa faktor yang mempengaruhi kinerja karyawan antara lain yaitu semangat, fasilitas yang diberikan perusahaan, rekan kerja, dan komitmen (Mahmudi, 2015).

Efektivitas adalah menggambarkan seluruh siklus input, proses dan output yang mengacu pada hasil guna daripada suatu organisasi, program atau kegiatan yang menyatakan sejauh mana tujuan (kualitas, kuantitas, dan waktu) telah dicapai, serta ukuran berhasil tidaknya suatu organisasi mencapai tujuannya dan mencapai target-targetnya. Hal ini berarti, bahwa pengertian efektivitas yang dipentingkan adalah semata-mata hasil atau tujuan yang dikehendaki

Seorang dosen harus dituntut memiliki kemampuan dan keterampilan tertentu. Kemampuan dan keterampilan tersebut sebagai bagian dari kompetensi profesionalisme dosen. Untuk menjadi dosen sebagai tenaga pengajar yang profesional harus perlu diadakan pembinaan secara terus menerus dan berkesinambungan melalui berbagai kegiatan, misalnya kegiatan penataran, pelatihan serta berkesempatan belajar ke jenjang pendidikan yang lebih tinggi. Namun perlu juga memperhatikan peningkatan profesionalitas dosen dari aspek yang lain seperti peningkatan disiplin, pemberian motivasi, pemberian bimbingan melalui supervisi, pemberian insentif, gaji yang layak dengan keprofesionalannya sehingga memungkinkan kinerja dosen diharapkan meningkat.

Berdasarkan uraian diatas, penulis tertarik untuk membuat penelitian dengan judul "Pengaruh Semangat Kerja, Hygiene Factor dan Employee Engagement Terhadap Efektivitas Organisasi"

\section{Perumusan Masalah}

Berdasarkan uraian latar belakang diatas peneliti merumuskan masalah yakni sebagai berikut:

1. Apakah semangat kerja berpengaruh terhadap efektivitas organisasi?

2. Apakah hygiene facktor berpengaruh terhadap efektivitas organisasi?

3. Apakah employee engagement berpengaruh terhadap efektivitas organisasi?

4. Apakah semangat kerja, hygiene factor dan employee engagement secara bersama-sama berpengaruh terhadap efektivitas organisasi?

\section{Tujuan Penelitian}

Sesuai dengan perumusan masalah yang telah diuraikan diatas, penelitian ini bertujuan untuk:

1. Untuk mengetahui pengaruh semangat kerja terhadap efektivitas organisasi 
2. Untuk mengetahui pengaruh hygiene factor terhadap efektivitas organisasi

3. Untuk mengetahui pengaruh employee engagement terhadap efektivitas organisasi

Untuk mengetahui pengaruh semangat kerja, hygiene factor dan employee engagement secara bersama-sama terhadap efektivitas organisasi

\section{TINJAUAN PUSTAKA}

\section{Pengertian Efektivitas Organisasi}

Efektivitas merupakan suatu pencapaian dari kegiatan sesuai dengan yang telah di rencanakan. Suatu pekerjaan yang telah di lakukan oleh seseorang tentu bisa menunjang untuk mencapai tujuan secara kelompok.

Efektivitas menurut Robbins ( Purnomo , 2006 : 36) adalah suatu keberhasilan dalam memenuhi tuntutan pelanggan / siswa dengan menggunakan input atau biaya yang rendah

Organisasi menurut Irawati ( 2013 : 10) adalah kumpulan dari orang-orang yang memiliki tujuan yang sama dan untuk memenuhi kebutuhan bersama , sedangkan menurut Siagian ( dalam Indrjid , 2013 : 12) Organisasi adalah segala bentuk persekutuan antara dua orang atau lebih yang bekerjasama untuk mencapai suatu tujuan bersama dan telah terikat secara formal dalam suatu ikatan hirarki antara sesorang atau sekelompok yang disebut pemimpi dan seorang atau sekelompok yang disebut bawahan (karyawan). Dapat disimpulkan efektivitas organisasi adalah tingkat ketepatan atau keberhasilan organisasi dalam mencapai tujuan yang sama antara pemimpin dan karyawan guna memenuhi kebutuhan bersama

Menurut Miller dalam Tangkilisan (2005) mengungkapkan bahwa: "effectiveness be define as the degree to which a social system achieve its goals. Effectiveness must be distinguished from efficiency. Efficiency is meanly concerd with goal attainment. Efektivitas dimaksud sebagai tingkat seberapa jauh suatu sistem sosial mencapai tujuannya. Efektivitas ini harus dibedakan dengan efisiensi. Efisiensi terutama mengandung pengertian perbandingan antara biaya dan hasil sedangkan efektivitas secara langsung dihubungkan dengan pencapaian suatu tujuan.

Menurut Bastian dalam Tangkilisan (2005) menyatakan efektivitas adalah hubungan antara output dan tujuan, dimana efektivitas diukur berdasarkan seberapa jauh tingkat output, kebijakan dan prosedur dari organisasi mencapai tujuannya.

Lebih lanjut dikatakan oleh Georgopualos dan Tannebaum dalam Tangkilisan (2005) mengenai pengertian efektivitas organisasi bahwa: "organization effectiveness as the extent to which an organization as a social system, given 
certain resources and mean, fulfill it's objective without incapacitating it's means and resources and without placing strain upon it's member". Efektivitas organisasi adalah tingkat sejauh mana suatu organisasi yang merupakan sistem sosial dengan segala sumber daya dan sarana tertentu yang tersedia memenuhi tujuan-tujuannya tanpa pemborosan dan menghindari ketegangan yang tidak perlu diantara anggota-anggotanya. Jadi secara umum ada pandangan bahwa efektivitas organisasi dimaksudkan atau dapat didefinisikan dalam batas-batas tingkat pencapaian tujuan organisasi. Efektivitas organisasi menurut Sedarmayanti (2009) sebagai tingkat keberhasilan

Melihat dari uraian mengenai efektivitas, organisasi dan efektivitas organisasi diatas, peneliti menyimpulkan bahwa efektivitas organisasi lebih dapat digunakan sebagai ukuran untuk melihat tercapai atau tidaknya suatu organisasi dalam melaksanakan kegiatan-kegiatan atau fungsi-fungsi sehingga tujuan yang telah ditetapkan dapat tercapai dengan menggunakan secara optimal alat-alat dan sumber-sumber yang ada.

\section{Semangat Kerja}

Semangat kerja menurut Bentley dan Rempel ( Majosry, 2007) adalah ketertarikan profesional dan antusiasme yang ditunjukkan sesorang yang mengarah pada prestasi individual serta tujuan kelompok dalam situasi kerja yang ada. Menurut Nitisemito perusahaan atau instansi akan mendapatkan keuntungan bila setiap individu yang bekerja memiliki semangat atau gairah kerja yang tinggi, semangat kerja yang tinggi biasanya akan dapat dilihat dari kesediaan individu untuk bekerja dengan sepenuh hati.

Semangat kerja yang baik dihubungkan dengan motif dan hasil kerja yang baik. Sedangkan semangat kerja yang rendah biasanya dihubungkan dengan kekecewaan, keengganan , kekurangan akan mendorong hasil kerja yang kurang baik. Sebab turunnya semangat kerja ada beberapa hal diantaranya karena upah yang terlalu rendah, insentif yang kurang, serta lingkungan kerja yang buruk. Turunnya semangat kerja yang dimiliki akan berdampak kepada pekerjaan dan organisasi. Semangat kerja yang buruk diasumsikan dapat menurunkan loyalitas pegawai terhadap organisasinya.

Semangat kerja adalah keinginan kesungguhan seseorang mengerjakan pekerjaannya dengan baik seta berdisiplin untuk mencapai prestasi kerja yang maksimal ( Hasibuan dalam Halimah: 2014)

Menurut Triadityo 2012 , semangat kerja adalah konsisi seseorang yang menunjang dirinya melakukan pekerjaan lebih cepat dan lebih baik. Suasana kerja pada umumnya dapat menjadi faktor penentu yang dapat membangkitkan semangat kerja karyawan. Contohnya : terciptanya suasana kekeluargaan diantara sesama rekan kerja dan suasana kerja yang kondusif. Hal tersebut dapat 
memberika reaksi positif bagi karyawan untuk meningkatkan semangat dan kegairahan kerja.

\section{Hygiene Factor}

Two factors theory oleh Herzberg (1950) (dalam Herzberg, 1974) kemudian muncul untuk menjelaskan faktor-faktor yang mempengaruhi motivasi kerja individu dalam rangka pemenuhan kebutuhan. Pada two factors theory terdapat dua faktor yang mempengaruhi motivasi kerja individu yakni motivator factors dan hygiene factors. Motivator factors berasal dari pekerjaan itu sendiri yang memicu munculnya kepuasan kerja. Hygiene factors tidak berasal dari pekerjaan itu sendiri dan dapat memicu timbulnya ketidakpuasan kerja. Adapun teori ini kemudian berkembang membentuk sejumlah teori baru yang behubungan dengan kompensasi, lingkungan kerja dan kepuasan kerja.

Aspek-aspek semangat kerja menurut Maier ( Majorsy, 2008) ada empat aspek semangat kerja yaitu :

1 Kegairahan atau antusiasme, secara tidak langsung berhubungan dengan motivasi yang tinggi. Dengan adanya kegairahan berarti ada minat yang akan mendorong individu untuk berupaya lebih keras dalam melakukan pekerjaan. Kegairahan atau antusiasme dapat memperkirakan motivasi pekerja pada pelaksanaan tugasnya

Kegairahan juga akan mendorong karyawan atau pekerja dalam melakukan pekerjaan dengan sebaik-baiknya.

2 Kualitas untuk bertahan, merupakan suatu keadaan yang menggambarkan situasi kelompok yang tidak kehilangan arah tujuan ketika menghadapi kesulitan, berarti ada ketekunan, penuh keyakinan dan saling memberi semangat antar karyawan. Menurut Alport ( Majosry, 2008) orang yang memiliki semangat kerja yang tinggi tidak akan mudah putus asa dalam menghadapi berbagai kesukaran yang muncul dalam pekerjaannya, berarti orang tersebut memiliki energi dan kepercayaan untuk memandang masa depan dengan baik, hal tersebut dapat meningkatkan kualitas seorang untuk bertahan.

3 Kekuatan untuk melawan frustasi menggambarkan bagaimana orang yang memiliki semangat kerja yang tinggi tidak memiliki sikap yang pesimis apabila menemui kesulitan pekerjaannya.

4 Semangat kelompok, menggambar hubungan antara karyawan . Dengan adanya semangat kelompok maka karyawan lebih berpikir sebagai kami daripada saya, mereka akan saling tolong-menolong dan tidak saling bersaing untuk menjatuhkan, keberhasilan pada seorang karyawan dianggap sebagai keberhasilan kelompok. Semangat kelompok merupakan aspek semangat kerja yang jelas menggambarkan gejala kelompok dan 
merupakan salah satu karakteristik dasar kelompok untuk bekerja sama dan bertanggung jawab secara sosial.

\section{Employee Engagement}

Komitmen terhadap kesuksesan pekerjaan sering disebut sebagai employee engagement. Employee engangement merupakan suatu istilah yang relatif baru dalam ilmu sumber daya manusia dimana kata tersebut sering digunakan oleh lembaga konsultan yang khusus bergerak didalam bidang sumber daya manusia.

Employee engagement merupakan gagasan dalam perilaku organisasi yang menjadi daya tarik dalam beberapa tahun belakangan. Daya tarik ini timbul karena employee engagement berpengaruh pada kinerja sebuah perusahaan secara keseluruhan. Hal ini telah di buktikan oleh salah satu organisasi riset terkemuka sebagai hubungan emosional yang tinggi dimana seorang karyawan rasakan terhadap organisasinya yang mempengaruhinya untuk mengerahkan usaha yang bebas dan lebih besar untuk pekerjaannya ( Rusher, 2010 :74).

\section{METODE PENELITIAN}

Dalam penelitian ini berarti data langsung diambil dari mahasiswa akuntansi yang sedang berada di kampus. Pengumpulan data dilakukan dengan cara mendatangi langsung kampus dan membagikan kuesioner ke mahasiswa Akuntansi S1 yang berada di lingkungan Universitas Pamulang dengan menggunakan Skala Likert. Untuk mengukur peneliti menggunakan Skala Likert berkala 5 dengan skor pada tabel 3.1 pada lampiran.

Sampel adalah bagian dari jumlah dan karakteristik yang dimiliki oleh populasi tersebut (Sugiyono, 2016: 81). Jumlah mahasiswa yang terdaftar pada periode 2017-2018 sebanyak 11.076. Namun responden dalam penelitian ini hanya berfokus pada mahasiswa semester 8-14 yang terdata pada tahun 2017-2018. Hal ini dikarenakan mahasiwa semester 8-14 dianggap sudah berhubungan lebih lama dengan para dosen dan karyawan sehingga diharapkan dapat memberikan penilaian yang lebih akurat.

Jumlah keseluruhan mahasiswa semester 8-14 adalah sebanyak 4.021 mahasiswa (data diambil dari staf administrasi prodi akuntansi melalui sistem sia@unpam.ac.id). Berhubung jumlah mahasiswa semester 8-14 yang terdaftar sebanyak 4.021 mahasiswa maka penulis menentukan jumlah responden menggunakan rumus slovin.

$$
\begin{aligned}
& n=\frac{N}{1+N e^{2}} \\
& \text { Keterangan: } \\
& \mathrm{n}=\text { ukuran sampel } \\
& \mathrm{N}=\text { ukuran populasi }
\end{aligned}
$$


$\mathrm{e}=$ batas kesalahan

Pengambilan sampel dalam penelitian ini diambil dari nilai error variansnya atau e $=10 \%$ shingga tingakt kebenaran sebesar $90 \%$, maka

$$
\mathrm{n}=\underline{4.021}=\frac{4.021}{1+4.021}=99,7
$$

Maka dibulatkan menjadi 100 responden mahasiswa semester 8-14 tahun ajaran 2017-2018.

\section{ANALISIS DATA DAN DISKUSI HASIL}

\subsection{Analisis Statistik Deskriptif}

Variabel-variabel yang digunakan dalam penelitian ini adalah kualitas kerja, kualitas pelayanan dan kepuasan mahasiswa akan diuji secara statistik deskriptif seperti yang terlihat ditabel yang ada pada lampiran.

Adapun uraian dan penjelasan dari tabel 4.1 mengenai hasil uji statistic deskriptif adalah sebagai berikut:

1. Rata-rata hitung dari variabel kualitas kerja (X1) menjelaskan bahwa jawaban minimum responden sebesar 14 dan jawaban maksimum responden sebesar 25 , rata-rata total jawaban responden adalah 22,17 yang menunjukkan bahwa keseluruhan jawaban responden terhadap kepuasan mahasiswa dapat diperoleh nilai 2,21 (22,17/100). Nilai 2,21 mewakili seluruh jawaban responden, bahwa sebagian besar responden ragu-ragu dengan pernyataan dari kualitas kerja (dilihat dari skala likert).

2. Rata-rata hitung dari variabel kualitas pelayanan (X2) menjelaskan bahwa jawaban minimum responden sebesar 15 dan jawaban maksimum responden sebesar 25, rata-rata total jawaban responden adalah 21,83 yang menunjukkan bahwa keseluruhan jawaban responden terhadap kepuasan mahasiswa dapat diperoleh nilai 2,18 (21,83/100). Nilai 2,18 mewakili seluruh jawaban responden, bahwa sebagian besar responden ragu-ragu dengan pernyataan dari kualitas pelayanan (dilihat dari skala likert).

3. Rata-rata hitung dari variabel kepuasan mahasiswa (Y) menjelaskan bahwa jawaban minimum responden sebesar 11 dan jawaban maksimum responden sebesar 25, rata-rata total jawaban responden adalah 20,39 yang menunjukkan bahwa keseluruhan jawaban responden terhadap kepuasan mahasiswa dapat diperoleh nilai 2,03 (20,39/100). Nilai 2,03 mewakili seluruh jawaban responden, bahwa sebagian besar responden ragu-ragu dengan pernyataan dari kepuasan (dilihat dari skala likert). 


\subsection{Uji Kualitas Data}

\section{Uji Validitas Data}

Uji validitas digunakan untuk mengukur sah atau valid tidaknya suatu kuesioner. Ghozali (2016:53) mengungkapkan bahwa uji validitas dilakukan dengan membandingkan nilai rhitung dengan rtabel untuk degree of freedom $(\mathrm{df})=\mathrm{n}-2$, dalam hal ini $\mathrm{n}$ adalah jumlah sampel. Pada penelitian ini sampel yang digunakan adalah 100 responden maka besarnya df adalah $100-2=98$, dengan $\mathrm{df}=98$ dan $\alpha=0,05$ sehingga didapat rtabel $=0,1966$. Berdasarkan hasil penelitian, dapat diketahui bahwa semua pernyataan dikatakan valid, karena berkorelasi secara positif dengan rhitung > rtabel, tabel hasil uji validitas terdapat pada lampiran.

\section{Uji Reliabilitas}

Ghozali (2016:47) mengatakan bahwa reliabilitas adalah alat untuk mengukur suatu kuesioner yang merupakan indikator dari variabel atau kontruk. Adapun cara yang digunakan untuk menguji reliabilitas kuesioner dalam penelitian ini adalah menggunakan rumus koefisien cronbach alpha $(\alpha)$. Suatu variabel dikatakan reliabel jika memiliki koefisien cronbach alpha > taraf 0,70. Hasil pengolahan data uji reliabiltas pada aplikasi SPSS terdapat pada lampiran tabel 4.3. Berdasarkan tabel 4.3 diketahui bahwa cronbach alpha atas variabel kualitas kerja sebesar 0,807, variabel kualitas pelayanan sebesar 0,700, dan kepuasan mahasiswa sebesar 0,814 . Uji reliabilitas tersebut menunjukan hasil cronbach alpha lebih dari 0,70 sehingga dapat disimpulkan bahwa semua item pernyataan kuesioner semua variabel adalah reliabel artinya apabila pernyataan itu diajukan kembali akan memperoleh jawaban yang relatif sama dengan jawaban sebelumnya.

\subsection{Uji Asumsi Klasik}

\subsubsection{Uji Normalitas}

Uji normalitas ini bertujuan untuk menguji apakah variabel independen dan variabel dependen, keduanya memiliki distribusi normal atau tidak. Gambar dibawah ini adalah hasil dari uji normalitas data dengan menggunakan grafik Normal Probability Plot. Gambar Histogram dapat dilihat dilampiran pada Gambar 4.1 Normalitas Histogram 4.1.

Dari hasil pengujian pada grafik normal histogram terlihat grafik lonceng kualitas kerja dan kualitas pelayanan terhadap kepuasan mahasiswa berada ditengah dan tidak condong ke kiri maupun ke kanan. Berdasarkan hasil gambar tersebut dapat disimpulkan bahwa model regresi layak untuk dipakai karena menunjukkan pola distribusi normal dan memenuhi asumsi normalitas. 


\subsubsection{Uji Multikolinearitas}

Uji multikolinearitas ini dilakukan untuk menguji apakah terdapat korelasi antara tiap variabel independen pada model regresi. Untuk melihat apakah ada atau tidaknya multikoliniaritas pada penelitian ini, dapat digunakan dengan dilihat melalui nilai Tolerance dan Variance Inflation factor (VIF). Jika nilai VIF kurang dari 10 dan tolerance lebih dari 0,10 maka tidak terjadi multikolinearitas dan sebaliknya. Tabel dapat dilihat dilampiran pada Tabel 4.4.

Dari gambar yang ada dapat dilihat bahwa masing-masing variabel bebas mempunyai nilai Variance Inflation Factor (VIF) kurang dari 10 dan tolerance lebih dari 0,10. Nilai tolerance pada variabel kualitas kerja sebesar 0,595 dengan nilai VIF sebesar 1,682. Nilai tolerance dari kualitas pelayanan sebesar 0,595 dengan nilai VIF sebesar 1,682. Oleh karena itu, dapat disimpulkan bahwa tidak terjadi multikoliniaritas antar variabel bebas dalam model regresi.

\subsubsection{Uji Heteroskedastisitas}

Ghozali (2016:134) mengatakan bahwa uji heteroskedastisitas bertujuan menguji apakah dalam model regresi terjadi ketidaksamaan variance dari residual satu pengamatan ke pengamatan yang lain. Dalam uji heterokedastisitas ini ditentukan dengan melihat grafik plot (scatterplot) seperti gambar pada lampiran pada Gambar 4.2 Heteroskedastisitas Scatterplot 4.2.

Dengan melihat hasil grafik scatterplot tersebut, dapat disimpulkan bahwa titik menyebar dibawah dan diatas angka nol (0) pada sumbu Y dan titik-titik tersebut tidak membentuk pola tertentu. Oleh karena itu, dapat disimpulkan model regresi tersebut tidak terjadi masalah heterokedastisitas.

\subsection{Uji Regresi Linear Berganda}

Uji regresi linear berganda merupakan suatu teknik yang digunakan untuk menghitung seberapa jauh hubungan antara beberapa variabel bebas (independen) dengan variabel terikat (dependen). Analisis ini untuk mengetahui pengaruh suatu variabel kualitas kerja, kualitas pelayanan, dan kepuasan mahasiswa. Persamaan regresi yang digunakan dapat dilihat pada tabel 4.5 dilampiran.

Dari tabel 4.5 diperoleh persamaan regresi sebagai berikut:

$$
\begin{aligned}
& \mathrm{Y}=\alpha+\beta 1 \mathrm{X} 1+\beta 2 \mathrm{X} 2 \mathrm{e} \\
& \mathrm{Y}=0,067+0,573 \mathrm{X} 1+0,343 \mathrm{X} 2+\mathrm{e}
\end{aligned}
$$

Dari hasil persamaan regresi diatas menunjukkan bahwa:

1. Nilai konstanta sebesar 0,067 menunjukkan besarnya kepuasan mahasiswa di Universitas Pamulang apabila variabel kualitas kerja dan kualitas pelayanan sama dengan nol atau tidak memberikan pengaruh. 
2. Nilai koefisien regresi pada variabel kualitas kerja (X1) sebesar 0,573 hal ini berarti jika variabel kualitas kerja bertambah satu satuan maka variabel kepuasan mahasiswa akan bertambah sebesar 0,573 dengan catatan variabel lain dianggap konstan.

3. Nilai koefisien regresi pada variabel kualitas pelayanan (X2) sebesar 0,343, hal ini berarti jika variabel kualitas pelayanan bertambah satu satuan maka variabel kepuasan mahasiswa akan meningkat sebesar 0,343 dengan catatan variabel lain dianggap konstan.

\subsection{Uji Koefisien Korelasi}

Uji koefisien korelasi adalah angka yang menunjukkan kuat atau lemahnya pengaruh antara dua variabel. Koefisien korelasi menunjukkan seberapa besar hubungan yang terjadi antara variabel independen (X1, X2, ) secara bersama-sama dengan variabel dependen (Y). Nilai $\mathrm{R}$ berkisar antara 0,00 sampai dengan 1,00, jika nilai semakin mendekati 1,00, maka hubungan yang terjadi semakin kuat, sebaliknya apabila nilai semakin mendekati 0,00 maka hubungan yang terjadi lemah. Berdasarkan tabel 4.5, dapat terlihat bahwa diperoleh $\mathrm{R}$ hitung sebesar 0,700 . Hal menunjukkan bahwa terjadi hubungan yang kuat antara variabel dependen dan variabel independen.

\subsection{Uji Koefisien Determinasi}

Koefisien determinasi adalah alat guna untuk mengetahui seberapa besarpengaruh variabel bebas atau independen yaitu kualitas kerja (X1), kualitas pelayanan (X2), terhadap variabel terikat atau dependen yaitu kepuasan mahasiswa (Y).

Dari tabel 4.5 dapat dilihat bahwa nilai koefisien determinasi (Adjusted $R 2$ Square) adalah 0,490 atau $49 \%$. Hal ini mengidentifikasi bahwa besarnya pengaruh kepuasan mahasiswa sebesar $49 \%$ yang dipengaruhi oleh pengaruh kualitas kerja, kualitas pelayanan dan sisanya sebesar 51\% dapat dipengaruhi oleh faktor lain seperti lokasi, harga, dan lain-lain.

\subsection{Uji Statistik t}

Uji statistik t digunakan untuk mengetahui pengaruh masing-masing variabel independen terhadap variabel dependen, di mana kualitas kerja (X1), kualitas pelayanan (X2), terhadap kepuasan mahasiswa (Y), maka digunakan uji $\mathrm{t}$ menggunakan SPSS, dimana $\mathrm{df}=\mathrm{n}-\mathrm{k}$ berarti 100-2 $=98$ dengan tingkat kesalahan 5\%, maka diperoleh ttabel $=1,66055$. Hasil uji t secara parsial pada tabel 4.5 dapat dilihat bahwa variabel kualitas kerja (X1) terhadap kepuasan mahasiswa (Y) menunjukkan nilai thitung > ttabel atau 6,586>1,66055 dengan tingkat signifikan sebesar 0,000 . Karena nilai signifikan variabel kualitas kerja (X1) lebih kecil dari $0,05(0,000<0,05)$, sehingga dapat disimpulkan bahwa H1 
diterima artinya kualitas kerja berpengaruh signifikan terhadap kepuasan mahasiswa. Hasil uji t secara parsial pada tabel 4.5 dapat dilihat bahwa variabel kualitas pelayanan (X2) terhadap kepuasan mahasiswa (Y) menunjukan nilai thitung > ttabel atau 3,877>1,66055 dengan tingkat signifikan lebih besar dari $0,05(0,000>0,05)$, sehingga dapat disimpulkan bahwa $\mathrm{H} 2$ diterima artinya kualitas pelayanan berpengaruh signifikan terhadap kepuasan mahasiswa. Hal tersebut menunjukkan bahwa kualitas pelayanan berpengaruh positif terhadap kepuasan mahasiswa.

\subsection{Uji Statistik F}

Uji statistik F pada dasarnya menunjukkan apakah variabel independen atau bebas yang dimasukkan mempunyai pengaruh secara bersama-sama terhadap variabel dependen atau terikat. Dengan tingkat kesalahan 5\%, dimana derajat kebebasan yakni df $1=\mathrm{k}-1$ sedangkan $\mathrm{df} 2=\mathrm{n}-\mathrm{k}$, maka df $1=2-1=1$ sedangkan df2=100-2=98, maka diperoleh Ftabel= 3,94. Hasil uji $F$ dalam Output SPSS dapat dilihat pada tabel 4.6 Anova dilampiran. Dari hasil uji F pada tabel 4.6 dapat dilihat bahwa hasil Fhitung sebesar 56,312, artinya nilai Fhitung > Ftabel (56,312 $>3,94$ ) dengan nilai signifikan sebesar 0,000. Karena nilai signifkansi lebih kecil daripada $0,05(0,000<0,05)$. Maka dapat disimpulkan bahwa $\mathrm{H} 3$ diterima artinya kualitas kerja (X1) dan kualitas pelayanan (X2) secara simultan berpengaruh signifikan terhadap Kepuasan Mahasiswa (Y).

\subsection{Diskusi Hasil dan Pembahasan}

\section{Pengaruh Kualitas Kerja Terhadap Kepuasan Mahasiswa.}

Hasil analisis statistik deskriptif terhadap kualiast kerja dapat diperoleh nilai 2,21 (22,17/100). Nilai 22,17 mewakili seluruh jawaban responden, bahwa sebagian besar responden ragu-ragu dengan pernyataan dari kualitas kerja. Hasil uji t secara parsial pada tabel 4.5 dapat dilihat bahwa variabel kualitas kerja (X1) terhadap kepuasan mahasiswa (Y) menunjukkan nilai thitung > ttabel atau 6,586>1,66055 dengan tingkat signifikan sebesar 0,000. Karena nilai signifikan variabel kualitas kerja (X1) lebih kecil dari 0,05 $(0,000<0,05)$, sehingga dapat disimpulkan bahwa $\mathrm{H} 1$ diterima artinya kualitas kerja berpengaruh signifikan terhadap kepuasan mahasiswa. Hal tersebut menunjukkan bahwa kualitas kerja berpengaruh positif terhadap kepuasan mahasiswa.

\section{Pengaruh Kualitas Pelayanan Terhadap Kepuasan Mahasiswa}

Hasil analisis statistik deskriptif terhadap kualitas pelayanan diperoleh nilai 2,18 (21,83/100). Nilai 2,18 mewakili seluruh jawaban responden, bahwa sebagian besar responden setuju dengan pernyataan dari kualitas pelayanan. Hasil uji t secara parsial pada tabel 4.5 dapat dilihat bahwa variabel kualitas pelayanan (X2) terhadap kepuasan mahasiswa (Y) menunjukan nilai thitung > 
ttabel atau 3,877> 1,66055 dengan tingkat signifikan lebih besar dari 0,05 $(0,000<0,05)$, sehingga dapat disimpulkan bahwa $\mathrm{H} 2$ diterima artinya kualitas pelayanan berpengaruh signifikan terhadap kepuasan mahasiswa. Hal tersebut menunjukkan bahwa kualitas pelayanan berpengaruh positif terhadap kepuasan mahasiswa.

\section{Pengaruh Kualitas Kerja dan Kualitas Pelayanan Terhadap Kepuasan Mahasiswa}

Dari hasil uji F pada tabel 4.6 dapat dilihat bahwa hasil Fhitung sebesar 56,312 artinya nilai Fhitung > Ftabel $(56,312>3,94)$ dengan nilai signifikan sebesar 0,000. Karena nilai signifkansi lebih kecil daripada $0,05(0,000<0,05)$. Maka dapat disimpulkan bahwa H3 diterima artinya Kualitas Kerja (X1) dan Kualitas Pelayanan (X2) secara simultan berpengaruh signifikan terhadap Kepuasan Mahasiswa (Y)

\section{KESIMPULAN}

Berdasarkan data yang diperoleh dalam penelitian mengenai kualitas kerja dan kualitas pelayanan terhadap kepuasan mahasiswa. Adapun responden dalam penelitian ini berjumlah 100 mahasiswa Akuntansi S1 yang sedang belajar di Universitas Pamulang, kemudian dilakukan berbagai uji statistik dan dianalisis sehingga menghasilkan kesimpulan sebagai berikut:

1. Hasil uji t secara parsial pada variabel kualitas kerja (X1) terhadap kepuasan mahasiswa (Y) menunjukkan nilai thitung > ttabel dengan tingkat signifikansi lebih kecil dari nilai probability t, maka $\mathrm{H} 1$ diterima artinya kualitas kerja berpengaruh signifikan terhadap kepuasan mahasiswa.

2. Hasil uji t secara parsial pada variabel kualitas pelayanan (X2) terhadap kepuasan mahasiswa (Y) menunjukkan nilai thitung > ttabel dengan tingkat signifikansi lebih kecil dari nilai probability t, maka $\mathrm{H} 2$ diterima artinya bahwa kualitas pelayanan terhadap kepuasan mahasiswa.

3. Dari hasil uji F diketahui bahwa Fhitung > Ftabel dengan nilai signifkansi lebih kecil dari nilai probability $\mathrm{F}$, maka $\mathrm{H} 3$ diterima artinya kualitas kerja dan kualitas pelayanan berpengaruh secara simultan dan signifikan terhadap kepuasan mahasiswa. 


\section{REFERENSI}

Buchari, Alma. (2007). Manajemen Pemasaran dan Pemasaran Jasa. Bandung: CV. Alfabeta

Dharmesta, Basu Swastha. (2003). Azas-azas Marketing. Yogyakarta : Liberti

Dharmesta, Basu Swastha. 2008. Manajemen Pemasaran Modern. Yogyakarta: Liberti

Ghozali, Mochamad. (2014). Pengaruh Kualitas Pelayanan dan Harga Terhadap Kepuasan Pelnaggan Pada Expedisi di Surabaya

Hasibuan, Malayu S.P. 2003. Manajemen Sumber Daya Manusia, Jakarta: Bumi Aksara

Kamus Besar Bahasa Indonesia, 2002:893

Kasan, Tholib. (2000). Teori dan Aplikasi Administrasi Pendidikan. Jakarta: Studia Press

Kotler, Philip \& Gary Amstrong. (2001). Prinsip-prinsip Pemasaran, Jilid II. Jakarta: Erlangga

Kotler, Amstrong. (2007). Dasar-dasar Pemasaran Edisi Bahasa Indonesia. Jakarta: PT. Prehallindo

Kotler, Phillip dan Hellen Keller. (2007). Manajemen Pemasaran Jilid 1 Alih Bahasa oleh Benyamin Molan Edisi 12. Jakarta: PT Indeks.

Kotler, Philip. (2009). Manajemen Pemasaran. Jakarta: Erlangga

Kotler, Philip. (2009). Manajemen Pemasaran, Jilid II, Edisi 11, Alih Bahasa Benyamin Molan. Jakarta: Indeks

Mulyasa, E. (2003). Manajemen Berbasis Sekolah. Bandung: PT. Remaja Rosdakarya.

Narimawati, Umi. (2008). Metodologi Penelitian Kualitatif dan Kuantitatif Teori dan Aplikasi

Rahman, Diandaris Nurhandika. (2013). Pengaruh Kualitas Pelayanan, Fasilitas, Persepsi Harga, dan Lokasi Terhadap Kepuasan Konsumen Pada Pemancingan Ngrembel Asri Gunung Pati Semarang.

Sugiyono. (2005). Statistik Untuk Penelitian Cetakan Kelima Bandung: CV. Alfabeta

Tjiptono, Fandy. (2006). Pemasaran Jasa Edisi Pertama Cetakan Kedua. Malang. Jawa Timur: Bayu Media Publishing

UU No. 20 tentang Sistem Pendidikan Nasional

PP No. 32 tahun 2013 tentang Standar Sarana dan Prasarana

http://theorymethod.blogspot.co.id/2015/12/jenis-dan-sumber-data.html

http://id.wikipedia.org/wiki/Manajemen).

http://www.pengertianpakar.com/2014/12/pengertian-dan-fungsi-pemasaran.html http://vickyindiarto.wordpress.com/2010/10/10/fungsi-fungsimanajemen/ http://id.wikipedia.org/wiki/Manajemen 
EkoPreneur

Vol. 1, No. 1, Des 2019
P-ISSN

E-ISSN

https://ristiyantihp25.wordpress.com/2015/10/26/4-fungsi-utama-dalammanajemen-poac/

https://www.slideshare.net/ChristianYLokas/30-definisi-manajemen-menurutpara-ahli-2786120 